\title{
Eotaxin levels in patients with primary dysmenorrhea
}

\author{
Evrim Gul' \\ Ebru Celik Kavak ${ }^{2}$ \\ 'Department of Emergency Medicine, \\ Elazig Education and Research \\ Hospital, Elazig, Turkey; ${ }^{2}$ Department \\ of Obstetrics and Gynecology, School \\ of Medicine, Firat University, Elazig, \\ Turkey
}

This article was published in the following Dove Press journal: Journal of Pain Research

Purpose: Primary dysmenorrhea (PD) is a common cause of pelvic pain that can cause limitations in daily activities. Treatment options sometimes result in failure, suggesting that different mechanisms may be effective in etiopathogenesis. Eosinophils are cells that are present in endometrium only in the perimenstrual period. The aim of this study was to evaluate the levels of eotaxin, a potent eosinophilic chemoattractant, in patients with PD.

Patients and methods: Thirty patients with PD and thirty healthy women were included in the study. Venous blood sample of $10 \mathrm{~mL}$ was collected from each participant. Blood samples were taken in the first 2 days of the menstrual cycle at any period of the day. Serum eotaxin levels were determined by enzyme-linked immunofluorescence assay.

Results: There were no statistically significant differences between the demographic properties of groups in terms of age and body mass index. Eotaxin levels were significantly different in patients with PD than the control subjects $(p=0.012)$.

Conclusion: Detection of different levels of eotaxin in patients with PD may be a new and important step in determining the factors contributing to the pathogenesis of dysmenorrhea.

Keywords: primary dysmenorrhea, eotaxin, eosinophil, ELISA, etiopathogenesis

\section{Introduction}

Primary dysmenorrhea (PD) is the pain in the pelvis or lower abdomen that begins several hours before or a few hours after the onset of menstrual bleeding. Symptoms usually last 1-3 days. The pain can be accompanied by symptoms such as nausea, vomiting, diarrhea, headache, dizziness, or low back pain. ${ }^{1}$

It is a common gynecologic problem and affects mainly adolescents and young adults. Its reported prevalence is between $20 \%$ and $95 \%$, and in $10 \%$ of patients symptoms interfere with the daily activities negatively. ${ }^{2,3}$

$\mathrm{PD}$ is associated with no pelvic pathology, and symptoms are mostly attributed to increased uterine activity and poor uterine blood circulation. ${ }^{4}$

Studies demonstrated that there is a prominent fluctuation in both the number and cell types of bone marrow-derived cells during different phases of the cycle in the endometrium. Chemoattractive cytokines, also known as chemokines, modulate the movement of lymphomyeloid cells from the circulation into the tissue. Eosinophils are not normally present in the endometrium and can only be seen in the endometrium, shortly before menstruation and during menstruation. ${ }^{5,6}$

Eotaxin is known as the most selective chemoattractant protein for eosinophils. ${ }^{7}$ Hornung et $\mathrm{al}^{8}$ assessed the localization of eotaxin in cells from normal endometrium
Correspondence: Ebru Celik Kavak Department of Obstetrics and Gynecology, School of Medicine, Firat University, Yahya Kemal Street, Elazig, 23100, Turkey

Tel +90 42423335552124

Fax +90 4242379138

Email eckavak@gmail.com; drkavak@yahoo.com.tr 
and endometriosis and found that eotaxin protein is mainly localized in epithelial cells with only faint staining in the peripheral tissues. They also demonstrated that epithelium of the secretory endometrium demonstrated a more prominent eotaxin accumulation than the proliferative-phase endometrium. A similar distribution of eotaxin was demonstrated in endometriosis, but the levels were higher.

In this study, we investigated the level of eotaxin in patients with PD and in healthy volunteers with no symptom of dysmenorrhea.

\section{Methods}

The protocol of the present study was approved by the local ethics committee of Frrat University. Written informed consents were obtained from each subject, and parental consent was obtained from participants under 18 years of age. Thirty patients with PD were enrolled from those who were admitted to emergency department of Elazı̆g Education Research Hospital (Group 1). Control group (Group 2) constituted 30, age-matched healthy volunteers. In patients with PD, the current pelvic pain started 6-12 months from the start of menarche. Pain occurred just before or during menses and lasted 1-3 days. All of them underwent pelvic ultrasonographic examination, and no pelvic pathology was seen in any of them. Neither the patients with PD nor the participants in the control group were married, and they did not have a sexual intercourse history. Subjects from both groups were nonsmokers. Their medical history revealed no abnormality. They did not have any history of allergy and associated diseases. Body mass index (BMI) and age of the participants were noted.

Venous blood sample of $10 \mathrm{~mL}$ was collected from each participant. Blood samples were taken in the first 2 days of the menstrual cycle at any period of the day. Participants were not fasting at the time of blood sampling. All the blood samples were centrifuged at 2,500 rpm for 15 minutes within an hour and the separated serum was stored at $-80^{\circ} \mathrm{C}$ until the analysis. Eotaxin levels were analyzed by using a commercial enzyme-linked immunosorbent assay kit (Sunred Human Eotaxin 1 Elisa Kit, Catolog number 201-12-0113, Shanghai Sunred Biological Technology Co., Ltd, Shanghai, People's Republic of China). The results are expressed as picograms per milliliter $(\mathrm{pg} / \mathrm{mL})$.

\section{Statistical analysis}

Data analysis was performed by using Statistical Package for Social Sciences (SPSS) version 22.0 software (SPSS Inc., Chicago, IL, USA). Data were expressed as mean $\pm \mathrm{SD}$.
Student's $t$-test was used for statistical analysis. $p$-value $<0.05$ was considered statistically significant.

\section{Results}

The demographic data and mean eotaxin levels for both groups are summarized in Table 1. The mean age was $17.1 \pm 0.9$ in patients with $P D$, and it was $16.6 \pm 0.8$ in the control group. Also the mean BMI was $22.0 \pm 0.8$ in the PD patients, and it was $21.5 \pm 0.7$ in the controls. There were no statistically significant difference between the groups in terms of age and BMI $(p>0.05)$

The mean eotaxin level was $440.72 \pm 132.17$ in healthy controls, and it was $580.8 \pm 195.7$ in patients with PD. The difference between the groups was statistically significant $(p=0.012)$. Characteristics of the subjects are shown in Table 1.

\section{Discussion}

Although the prevalence of PD is high and is a public health problem associated with substantial economic loss related to school or work absence, the diagnosis is often overlooked. Most of those who suffer from this situation do not receive appropriate and adequate treatment. Despite the proven efficacy profile of pharmacologic agents, $20 \%-25 \%$ of the patients still experience treatment failure. ${ }^{9}$ Therefore, we thought that different mechanisms might be also have an effect on the pathophysiology. We have tried to determine the level of eotaxin, an important chemoattractant agent for eosinophils, in patients with PD, based on the knowledge that eosinophils are only detected in endometrium just before and during the menstrual bleeding.

Eotaxin, a $8.3 \mathrm{kDa}$ protein, belongs to the chemokine group of cytokines and acts through the CCR3 receptors on eosinophils. ${ }^{10,11}$ It was first described in allergic airway inflammation in guinea pigs, but elevated eotaxin levels have also been reported in other pathologic conditions ranging from coronary heart disease to schizophrenia. ${ }^{12-14}$ Its wide distribution in many cell types in normal tissues and pathologic states give rise to the thought that it may have other

Table I Clinical and laboratory characteristics of the cases in Group I and Group 2

\begin{tabular}{llll}
\hline & $\begin{array}{l}\text { Group I } \\
(\mathbf{n}: 30)\end{array}$ & $\begin{array}{l}\text { Group 2 } \\
(\mathbf{n}: 30)\end{array}$ & p-values \\
\hline Age $($ Year $)$ & $17.1 \pm 0.9$ & $16.6 \pm 0.8$ & 0.21 \\
BMI $\left(\mathrm{kg} / \mathrm{m}^{2}\right)$ & $22.0 \pm 0.8$ & $21.5 \pm 0.7$ & 0.14 \\
Eotaxin $(\mathrm{pg} / \mathrm{mL})$ & $580.8 \pm 195.7$ & $440.72 \pm 132.17$ & 0.012 \\
\hline
\end{tabular}

Notes: The values are shown as mean \pm SD. Group I: patients with PD; Group 2: control group of healthy volunteers.

Abbreviations: BMI, body mass index; PD, primary dysmenorrhea. 
functions in the body. We herein studied eotaxin levels in patients with PD and in normal healthy participants and found that eotaxin levels were significantly higher in patients with PD. To the best of our knowledge, this is the first study examining the levels of eotaxin in PD.

Targowski et al ${ }^{15}$ demonstrated that age and sex are important determinants of the serum content of eotaxin in healthy people. In our study, there was no statistically significant difference between the ages of the groups.

Rocha et $\mathrm{al}^{16}$ studied the levels of some interleukins and eotaxin in patients undergoing surgery for gynecologic complaints and found that eotaxin levels modified by endometriosis may also be altered by other conditions with similar symptoms.

Prostaglandin pathway is known to be important in the pathophysiology of PD. Different factors may play an additive role in the pathogenesis of dysmenorrhea. The effect of vasopressin, NO, and histamine on uterus contraction have also been studied. ${ }^{17,18}$

The uterus has histamine receptors. Jarisch et $\mathrm{al}^{19}$ found that some women experience a drop in diamine oxidase levels and a consequent severe effect of histamine at the start of menstruation. Eosinophil cationic protein, also known as major basic protein, is a primary constituent of eosinophil granules. It has been demonstrated that major basic protein stimulates histamine release from basophils and mast cells. ${ }^{20}$ In clinical practice, the administration of $\mathrm{H} 1$ receptor on the first day of menstruation may prevent pain. The relationship between eotaxin and dysmenorrhea may be via histamine.

More studies with increased number of participants are needed to determine the exact role of eotaxin and its mechanism of action in PD.

\section{Disclosure}

The authors report no conflicts of interest in this work.

\section{References}

1. Proctor ML, Farquhar C. Diagnosis and management of dysmenorrhoea. BMJ. 2006;332(7550):1134-1138.

2. Harel Z. A contemporary approach to dysmenorrhea in adolescents. Paediatr Drugs. 2002;4(12):797-805.

Journal of Pain Research

Publish your work in this journal

The Journal of Pain Research is an international, peer reviewed, open access, online journal that welcomes laboratory and clinical findings in the fields of pain research and the prevention and management of pain. Original research, reviews, symposium reports, hypothesis formation and commentaries are all considered for publication.
3. Hsu CS, Yang JK, Yang LL. Effect of a dysmenorrhea Chinese medicinal prescription on uterus contractilit y in vitro. Phytother Res. 2003;17(7): 778-783.

4. Coco AS. Primary dysmenorrhea. Am Fam Physician. 1999;60(2): 489-496.

5. Jeziorska M, Salamonsen LA, Woolley DE. Mast cell and eosinophil distribution and activation in human endometrium throughout the menstrual cycle. Biol Reprod. 1995;53(2):312-320.

6. Poropatich C, Rojas M, Silverberg SG. Polymorphonuclear leukocytes in the endometrium during the normal menstrual cycle. Int J Gynecol Pathol. 1987;6(3):230-234.

7. White JR, Imburgia C, Dul E, et al. Cloning and functional characterization of a novel human CC chemokine that binds to the CCR3 receptor and activates human eosinophils. J Leukoc Biol. 1997;62(5):667-675.

8. Hornung D, Dohrn K, Sotlar K, et al. Localization in tissues and secretion of eotaxin by cells from normal endometrium and endometriosis. J Clin Endocrinol Metab. 2000;85(7):2604-2608.

9. Proctor ML, Murphy PA. Herbal and dietary therapies for primary and secondary dysmenorrhoea. Cochrane Database Syst Rev. 2001;(3): CD002124.

10. Garcia-Zepeda EA, Rothenberg ME, Ownbey RT, Celestin J, Leder P, Luster AD. Human eotaxin is a specific chemoattractant for eosinophil cells and provides a new mechanism to explain tissue eosinophilia. Nat Med. 1996;2(4):449-456.

11. Ponath PD, Qin S, Ringler DJ, et al. Cloning of the human eosinophil chemoattractant, eotaxin. Expression, receptor binding, and functional properties suggest a mechanism for the selective recruitment of eosinophils. J Clin Invest. 1996;97(3):604-612.

12. Jose PJ, Griffiths-Johnson DA, Collins PD, et al. Eotaxin: a potent eosinophil chemoattractant cytokine detected in a guinea pig model of allergic airways inflammation. J Exp Med. 1994;179(3):881-887.

13. Emanuele E, Falcone C, D'Angelo A, et al. Association of plasma eotaxin levels with the presence and extent of angiographic coronary artery disease. Atherosclerosis. 2006;186(1):140-145.

14. Teixeira AL, Reis HJ, Nicolato R, et al. Increased serum levels of CCL11/eotaxin in schizophrenia. Prog Neuropsychopharmacol Biol Psychiatry. 2008;32(3):710-714.

15. Targowski T, Jahnz-Rózyk K, Plusa T, Glodzinska-Wyszogrodzka E. Influence of age and gender on serum eotaxin concentration in healthy and allergic people. J Investig Allergol Clin Immunol. 2005;15(4): 277-282.

16. Rocha AL, Vieira EL, Maia LM, Teixeira AL, Reis FM. Prospective evaluation of a panel of plasma cytokines and chemokines as potential markers of pelvic endometriosis in symptomatic women. Gynecol Obstet Invest. 2016;81(6):512-517.

17. Bergant A, Lechner W, Sölder E, Huter O, Kölle D. Increased uterine activity through histamine. Zentralbl Gynakol. 1993;115(10):454-457.

18. Martínez-Mir MI, Estañ L, Morales-Olivas FJ, Rubio E. Effect of histamine and histamine analogues on human isolated myometrial strips. Br J Pharmacol. 1992;107(2):528-531.

19. Jarisch R. Histamine intolerance in women. In: Jarisch R, ed. Histamine Intolerance. Berlin: Springer; 2015:109-115. Available from: https:// link.springer.com/chapter/10.1007/978-3-642-55447-6_6.

20. O'Donnell MC, Ackerman SJ, Gleich GJ, Thomas LL. Activation of basophil and mast cell histamine release by eosinophil granule major basic protein. J Exp Med. 1983;157(6):1981-1991.

The manuscript management system is completely online and includes a very quick and fair peer-review system, which is all easy to use. Visit http://www.dovepress.com/testimonials.php to read real quotes from published authors. 